Jurnal Pemberdayaan: Publikasi Hasil Pengabdian kepada Masyarakat

Vol. 4, No. 3, Desember 2020, Hal. 347-354

ISSN: 2580-2569; e-ISSN: 2656-0542

DOI: https://doi.org/10.12928/jp.v4i3.2539

\title{
Pelatihan Baca Al-Qur'an dan Pendampingan Calon Santri Pondok Modern Darussalam Gontor di Masa Covid-19
}

\author{
Syaifullahil Maslul ${ }^{1}$, Thonthowi ${ }^{2}$, Fajar Fithroni ${ }^{3}$, Alan Sadewa ${ }^{1}$ \\ Universitas Islam Negeri Sunan Kalijaga, Jl. Marsda Adisucipto, Yogyakarta ${ }^{1}$ \\ Direktur Pesantren Mahasiswa Universitas Ahmad Dahlan, Jl. Ring Road Selatan, Bantul, \\ Yogyakarta ${ }^{2}$ \\ Universitas Ahmad Dahlan, Jl. Kapas No.9, Semaki, Kec. Umbulharjo, Yogyakarta ${ }^{3}$ \\ Email: syaifullahil.maslul@uin-suka.ac.id
}

\begin{abstract}
ABSTRAK
Pesantren merupakan salah satu khazanah dalam pendidikan Indonesia. Hal ini disebabkan model pendidikan yang berbeda dan alumni yang dihasilkan. Pondok Modern Darussalam Gontor adalah Pesantren yang telah berdiri sejak 1926. Model pendidikan dan peran alumni menjadi salah pertimbangan orang tua untuk memasukkan anaknya ke Pondok Modern Darussalam Gontor. Persayaratan masuk Pondok Modern Darussalam Gontor adalah kemampuan baca Al-Qur'an. Sebagai upaya untuk mempersiapkan calon santri diadakanlah pelatihan baca AlQur'an dan pendampingan calon santri. Kegiatan pengabdian dilaksanakan pada masa pandemi covid-19. Metode yang dipergunakan adalah metode sorogan daring dan mengirimkan materi video ke peserta. Untuk pendampingan dilaksanakan selama pendaftaran sampai pengumuman kelulusan. Pengabdian berjalan lancar dengan kelulusan peserta pelatihan sebesar 95,91\%. Para peserta yang lulus menjadi santri Pondok Modern Darussalam Gontor.
\end{abstract}

Kata Kunci: Pelatihan, Baca Qur’an, Santri

\section{ABSTRACT}

Pesantren is one of the treasures in Indonesian education. The reasons are the teaching model and graduates. Pondok Modern Darussalam Gontor is an Islamic boarding school which was established in 1926. The education model and the role of alumni are among the considerations of parents to enroll their children in Pondok Modern Darussalam Gontor. The requirement to enter Pondok Modern Darussalam Gontor is the ability to read the Qur'an. In an effort to prepare prospective students, a training was held in reading the Qur'an and assisting prospective students. Community service activities were carried out during the covid-19 pandemic. The method used is the online sorogan method and sends teaching video to participants. For assistance is carried out during registration until the announcement of graduation. Community service activiries are running well with percentage of graduation 95,91\%. The participants who graduated became Santri of Pondok Modern Darussalam Gontor.

Keywords: Training, Reading Qur'an, Santri

\section{PENDAHULUAN}

Sistem pesantren merupakan khazanah pendidikan yang dimiliki oleh Indonesia. Bahkan, eksistensi pesantren dalam dunia pendidikan telah mendahului lahirnya Indonesia. Dalam catatan sejarah, pesantren telah berdiri sejak abad ke 15 dan bertahan selama enam abad, atau paling tidak eksistensinya masih relevan sampai saat ini (Ismail 2011:48).

Sebagai bukti pengakuan negara terhadap pesantren, disahkahlan Undang-Undang Nomor 18 Tahun 2019 Tentang Pesantren (UU Pesantren). UU Pesantren adalah bukti nyata eksistensi pesantren dalam dunia pendidikan. Selain itu, Pesantren telah menjadi kelompok pendidik bangsa yang turut mencerdaskan kehidupan bangsa dan negara. Mukti Ali 
menyebutkan bahwa Ulama di Indonesia selalu dihasilkan oleh pondok pesantren (Syafe'i 2017:87). Pernyataan ini paling tidak memberikan kejelasan bahwa pesantren berkontribusi pada proses mencerdaskan kehidupan bangsa. Kontribusi ini secara spesifik pada proses pembentukan ulama dan secara umum mewarnai kehidupan berbangsa dan bernegara.

Salah satu pesantren yang ada di Indonesia adalah Pondok Modern Darussalam Gontor. Gontor didirikan oleh tiga Trimurti Pondok Modern Darussalam Gontor (Pondok Gontor), KH. Ahmad Sahal, KH. Zainuddin Fanani dan KH. Imam Zarkasyi pada Tahun 1926. Pondok Gontor adalah pesantren dengan model pembelajaran modern guna memperdalam tafaqquh $f i$ al-din. Model pembelajaran modern sebagaimana dimaksud terejawantahkan dari pendidikan yang menyeluruh meliputi aspek apa yang dilihat, apa yang didengarkan serta apa yang dirasakan oleh santri adalah bagian dari kegiatan belajar. Aspek-aspek tersebut adalah unsur yang dimaknai dan dijalankan oleh Pondok Gontor (Syamsuri 2016:217). Selain itu, Pondok Gontor juga menyatukan tiga pondasi pendidikan, yaitu keluarga, masyarakat dan sekolah (Hardoyo 2008:195).

Salah satu pendiri Pondok Gontor, KH. Zainuddin Fanani menyebutkan apa itu definisi modern dalam pendidikan. Modern disebutkan sebagai kewajiban kaum muslim berupa kewajiban sebagai manusia, kewajiban sebagai umat islam, kewajiban sebagai hamba Allah. Kesemua hal tersebut pada prinsipnya adalah upaya dalam hal pendidikan ruhani yang secara bersamaan merupakan inti dari pendidikan (Sanusi 2016:166). Selain itu, konsep kemodernan pesantren atau pondok modern merupakan solusi atas keberadaan pondok pesantren tradisional. Solusi tersebut muncul guna mempersiapkan santri untuk kesiapan santri hidup di masyarakat sesuai dengan bidang keahliannya. Solusi sebagaimana dimaskud terdiri dari pembaharuan di bidang kurikulum pesantren, penguatan di bidang manajemen kelembagaan pesantren dan penanaman etika pesantren sebagai tradisi (Nurhakim 2018:88)

Hasil pendidikan Pondok Gontor telah mewarnai Indonesia. Jaringan alumni yang kuat serta peran di tengah masyarakat telah menjadikan Pondok Gontor magnet yang mampu menarik perhatian khalayak serta menjadi pusat perhatian pendidikan. Peran alumni yang sedemikian besar berawal dari pendidikan karakter serta penanaman nilai-nilai selama di Pondok Gontor. Nilai-nilai inilah yang merasuk mendalam di sanubari para alumni Pondok Gontor ketika berkiprah di masyarakat.

Dalam urusan mendasar soal menuntut ilmu, KH. Imam Zarkasyi menyebutkan bahwa kepintaran tidak ada hubungannya dengan kekayaan, maka belajarlah bukan untuk kekayaan tetapi lillah ta'ala, (hanya untuk Allah), li i'lai kalimatillah ( untuk menegakkan kalimat Allah). Niat yang baik akan membimbing seseorang ke jalan kebermanfaatan ilmu dan keberkahannya. Kemanfaatan dan keberkahan ilmu dari niat baik akan dirasakan orang banyak. Namun, apabila salah niat dalam menuntut ilmu akan terjerumus ke dalam jurang kesesatan dan tidak bermanfaat ilmunya (Zarkasyi 2016:19)

Hal ini terbukti dari banyaknya orang tua yang berkeinginan untuk memasukkan anaknya ke Pondok Gontor. Tidak heran setiap pembukaan pendaftaran santri baru, Pondok Gontor selalu dipenuhi calon santri. Bahkan, di masa pandemi covid19, tidak menyurutkan minat calon santri masuk ke Pondok Gontor.

Pada Tahun 2019, jumlah pendaftar calon santri Pondok Gontor berjumlah 6530 (Hardoyo 2008). Jumlah pendaftar yang mencapai ribuan adalah bukti tingginya persaingan untuk menjadi santri Pondok Gontor. Selain itu, ujian masuk Pondok Gontor yang berbeda dengan sekolah dan pesantren pada umumnya. Ujian masuk Pondok Gontor terdiri dari dua ujian, pertama ujian lisan dan kedua ujian tulis.

Ujian lisan terdiri dari materi baca Qur'an, tajwid, ibadah Amaliyah, ibadah qouliyah, hafalan doa sehari-hari, juz amma dan wawancara singkat. Sedangkan materi ujian tulis terdiri dari, imla'/ dikte tulis arab, berhitung angka, berhitung soal dan bahasa indonesia. 
Tujuan pelaksanaan ini adalah untuk menyiapkan calon santri Pondok Gontor menghadapi ujian masuk. Pengabdian ini dilaksanakan dengan kegiatan pelatihan baca alQur'an dan pendampingan calon santri Pondok Gontor di masa covid-19. Selain itu, pelaksanaan pengabdian pada kesempatan kali ini berada di kondisi yang sangat berbeda. Pengabdian ini dilaksanakan di masa pandemi covid 19. Sehingga, pengabdian dilaksanakan secara daring/online.

\section{METODE}

Pelaksanaan pengabdian ini terdiri dari dua kegiatan. Pertama, pelatihan baca al-Qur'an bagi calon santri Pondok Gontor. Kegiatan ini bertepatan dengan musim pandemi covid-19. Pengabdian dilaksanakan dengan memperhatikan protokol kesehatan sesuai dengan arahan pemerintah.

Pengabdian pelatihan baca al-Qur'an dilaksanakan secara daring/online dengan menggunakan dua cara. Cara pertama dengan membagikan video pengajaran secara online yang dikirimkan melalui media sosial. Para peserta diminta untuk mempelajari materi yang dikirimkan kemudian memberikan waktu khusus untuk bertanya, meminta kejelasan dan membahas hal-hal yang dirasa memerlukan pendalaman materi.

Cara kedua dengan melakukan pelatihan baca al-Qur'an melalui media zoom. Pelatihan melalui media zoom dengan metode sorogan. Menurut Nurul Amin sebagaimana dikutip oleh Iys Nur Handayani adalah santri menghadap ustadz seorang demi seorang dengan membawa kitab yang dipelajari. Dalam hal ini, kitab yang dimaskud adalah al-Qur'an. sehingga, didapatkan pemahaman atas kualitas setiap santri yang kemudian dapat dievaluasi (Handayani and Suismanto 2018:105). Pelatihan ini selanjutnya disebut dengan sorogan zoom. Selama pelatihan, pemateri pengabdian memberikan materi pelatihan secara mendalam dengan memahami karakteristik calon santri sekaligus mengevaluasinya.

Pengabdian yang kedua adalah pendampingan calon santri dari proses pendaftaran dan sampai pengumuman kelulusan santri Pondok Gontor. Alasan pengabdian ini dilaksanakan karena penerimaan santri Pondok Gontor berada di musim pandemi covid-19. Para calon santri hanya dapat berangkat sendiri tanpa disertai wali mereka. Hal ini menggerakan para pengabdi untuk ikut mendampingi para calon santri, khususnya yang masih belum terbiasa jauh dari orang tua.

Kegiatan pelatihan baca al-Qur'an dilaksanakan pada tanggal 29 April 2020- 20 Mei 2020. Sedangkan kegiatan pendampingan dilaksanakan pada tanggal 17 Juni 2020 sampai diumumkannya kelulusan santri Pondok Gontor pada 27 Juni 2020.

Pengabdian ini melibatkan mahasiswa dari dua universitas. Pertama, Fajar Fithroni selaku mahasiswa Universitas Ahmad Dahlan. Kedua, Alan Sadewa selaku mahasiswa Univeristas Islam Negeri Sunan Kalijaga Yogyakarta. Selain itu, mitra yang dilibatkan dalam kegiatan ini adalah Ikatan Alumni Pondok Modern Cabang Yogyakarta (IKPM Yogyakarta).

\section{HASIL, PEMBAHASAN DAN DAMPAK}

\section{Pelatihan Baca Al-Qur'an Bagi Calon Santri Pondok Gontor}

Sesuai dengan data yang masuk, jumlah peserta pada pelatihan baca al-Qur' an berjumlah 108 peserta calon santri Pondok Gontor. Peserta terbagi menjadi 2 kelompok. Pertama, kelompok calon santri putra yang berjumlah 50 peserta dan kedua kelompok calon santri putri berjumlah 58 peserta. Dari data yang tersaji, dapat digambarkan grafik sesuai kelompok, seperti tampak pada Gambar 1. 


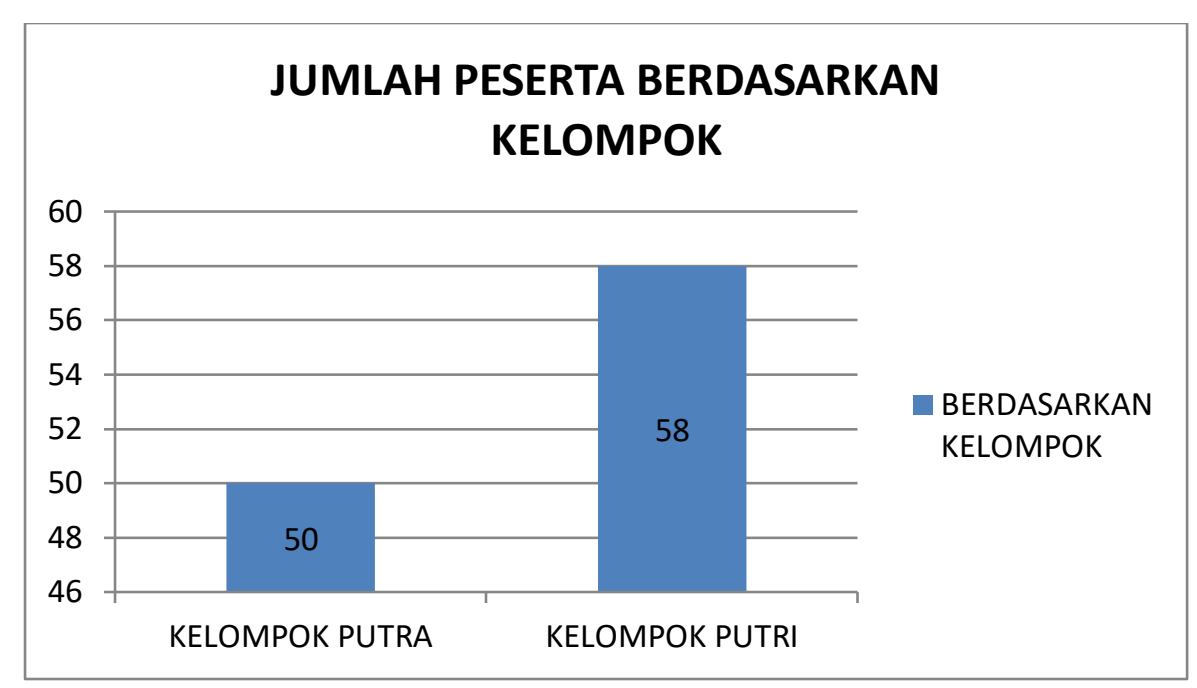

Gambar 1. Jumlah Peserta Berdasarkan Kelompok

Sebagai bahan acuan penilaian, pengabdian ini melakukan penilaian secara pretest dan posttest. Pretest dan posttest adalah serangkaian kegiatan untuk dapat membaca perkembangan pengajaran atau pelatihan. Metode ini dapat meningkatkan hasil belajar peserta calon santri. Pretest memberikan stimulus pembelajaran sehingga kesiapan peserta terhadap pelajaran dan ujian lebih baik. Sedangkan posttest memiliki manfaat untuk melihat sampai sejauh mana keefektifan pelatihan. Data pretest akan dibandingkan dengan hasil posttest untuk dijadikan bahan evaluasi pembelajaran (Effendy 2016:83). Selanjutnya, hasil pretest dan posttest disajikan pada Gambar 2.

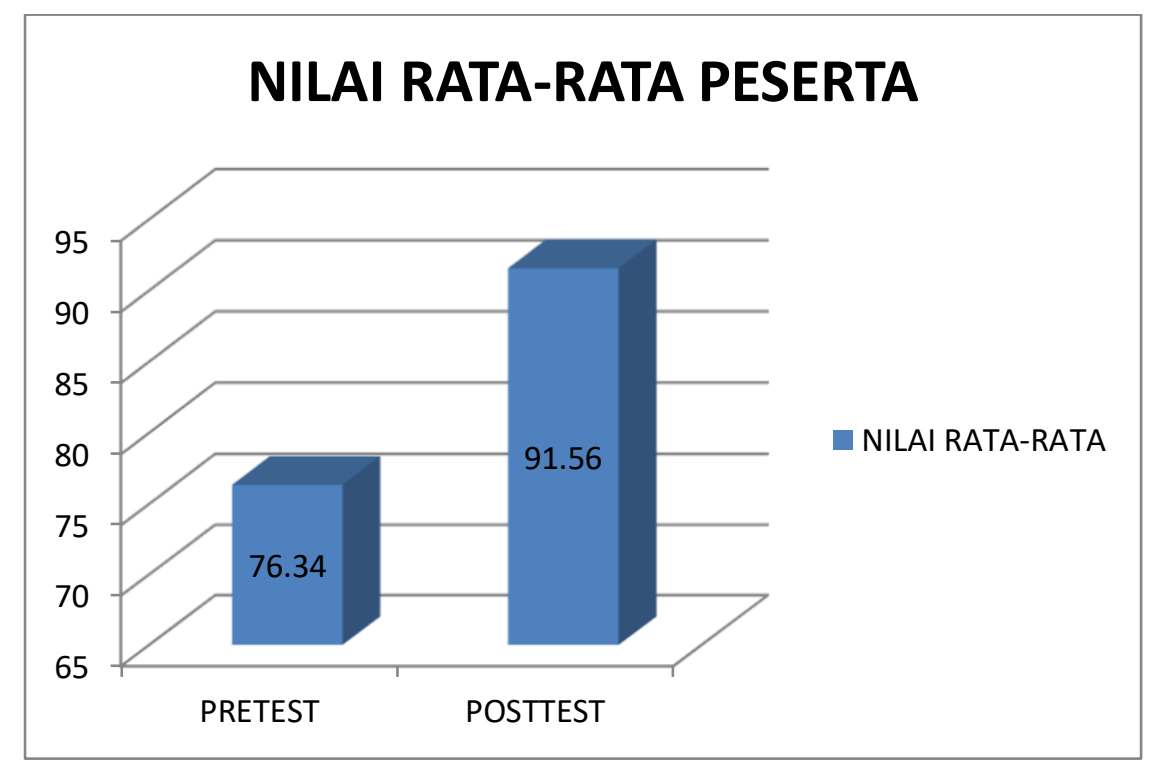

Gambar 2. Nilai Pretest Dan Posttest

Dari data yang tersaji dapat dijabarkan kegiatan pelatihan ini berjalan dengan baik dan memberikan dampak signifikan. Signifikansi ini dapat terlihat dari peningkatan nilai. Pada saat pretest, peserta rata-rata mendapatkan nilai 76,34 sedangkan pada saat posttest nilai rata-rata peserta berjumlah 91,56. Ada peningkatan sejumlah 15,22 dari nilai rata-rata. Kegiatan pelatihan baca al-Qur'an berlangsung selama 20 hari dari tanggal 29 April 2020 sampai dengan 
tanggal 20 Mei 2020. Kegiatan dilaksanakan secara daring/online melalui aplikasi zoom serta pengiriman video pengajaran, seperti tampak pada Gambar 3.

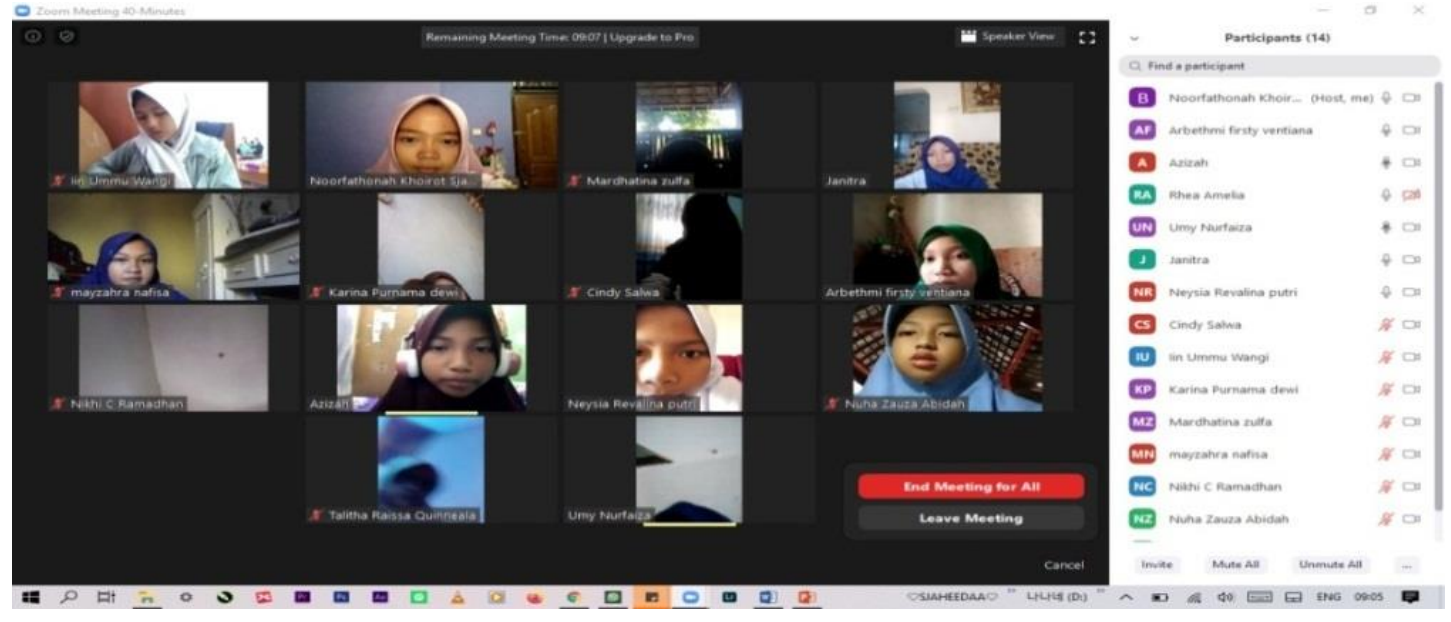

Gambar 3. Sorogan Pelatihan Baca Al-Qur'an Secara Darin

Setelah pelatihan selama 20 hari, tahapan berikutnya adalah pendaftaran dan ujian masuk Pondok Gontor. Ujian masuk merupakan ujian seleksi untuk calon santri yang dilaksanakan oleh Pondok Gontor. Sebagai catatan, ada beberapa peserta pelatihan yang tidak mengikuti pendaftaran dengan berbagai alasan. Data peserta pelatihan yang mengikuti ujian seleksi masuk Pondok Gontor disajikan pada Gambar 4.

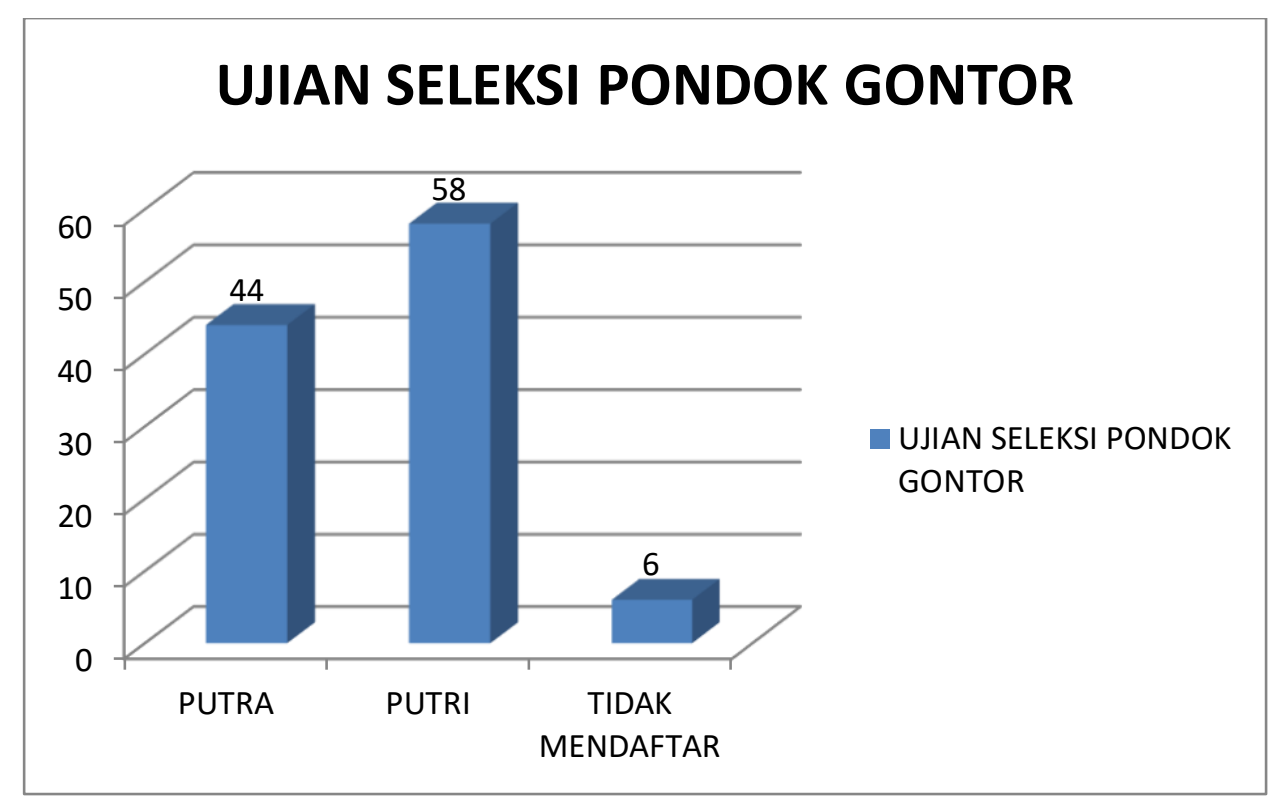

Gambar 4. Peserta Pelatihan Yang Mendaftar Ujian Seleksi Masuk Pondok Gontor

Setelah mengikuti ujian seleksi, dapat dipetakan kelulusan para calon santri. Pengukuran terhadap hasil pelatihan dilaksanakan hanya bagi peserta pelatihan yang mengikuti ujian seleksi masuk Pondok Gontor. Bagi yang tidak mengikuti tidak dapat dilaksanakan pengukuran kualitas hasil pelatihan.

Gambar 5 dan 6 menunjukkan dua grafik yang memiliki 2 jenis kesimpulan. Pertama, kelulusan peserta pelatihan mencapai 95,91\%. Peserta lulus terdiri dari kelompok putra dan putri. Hal ini merupakan capaian yang luar biasa melihat kondisi pelatihan yang tidak 
dilaksanakan secara tatap muka. Kedua, peserta yang tidak lulus hanya berjumlah 4,09\% yang menandakan rendahnya prosentase ketidak lulusan. Hal ini sangat kontras dengan capaian peserta pelatihan yang lulus. Sehingga, dapat disimpulkan bahwa pelatihan ini berdampak signifikan.

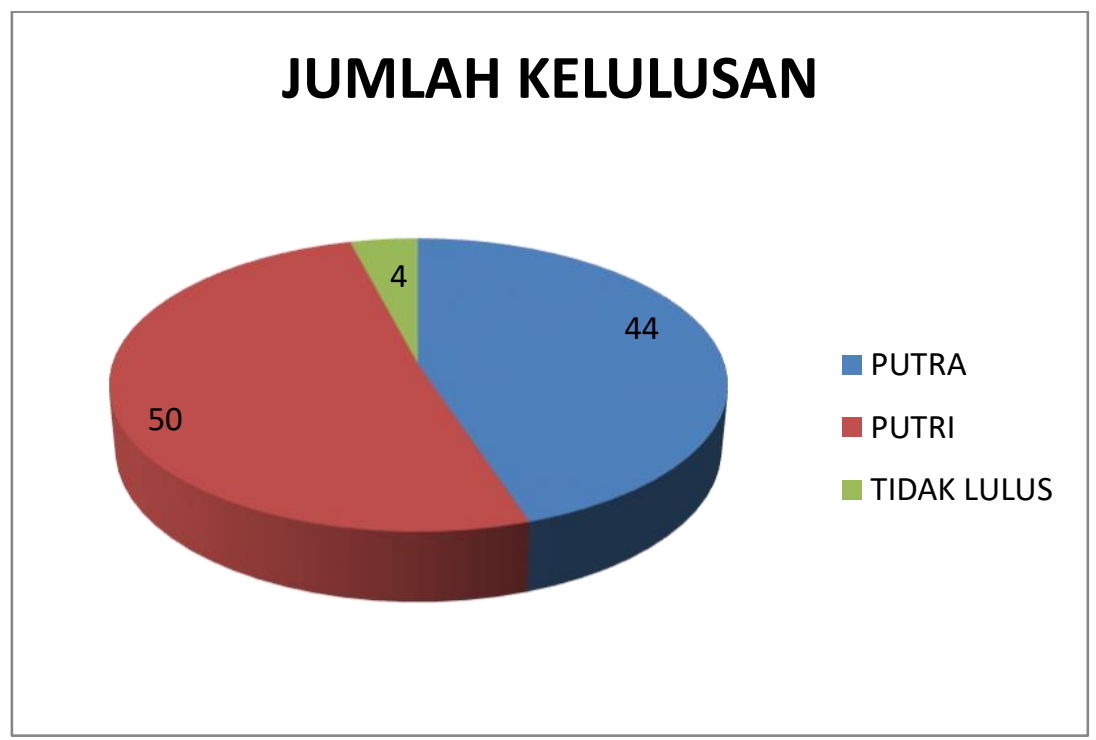

Gambar 5. Kelulusan Peserta Pelatihan

Sebagai data tambahan, perlu disajikan persebaran calon peserta di Pondok Gontor. Penyajian data ini disebabkan dua hal (Gambar 7 dan 8). Pertama, Pondok Gontor yang telah tersebar di seluruh Indonesia dan memiliki banyak cabang. Kedua, sebagai evaluasi untuk peningkatan kegiata selanjutnya.

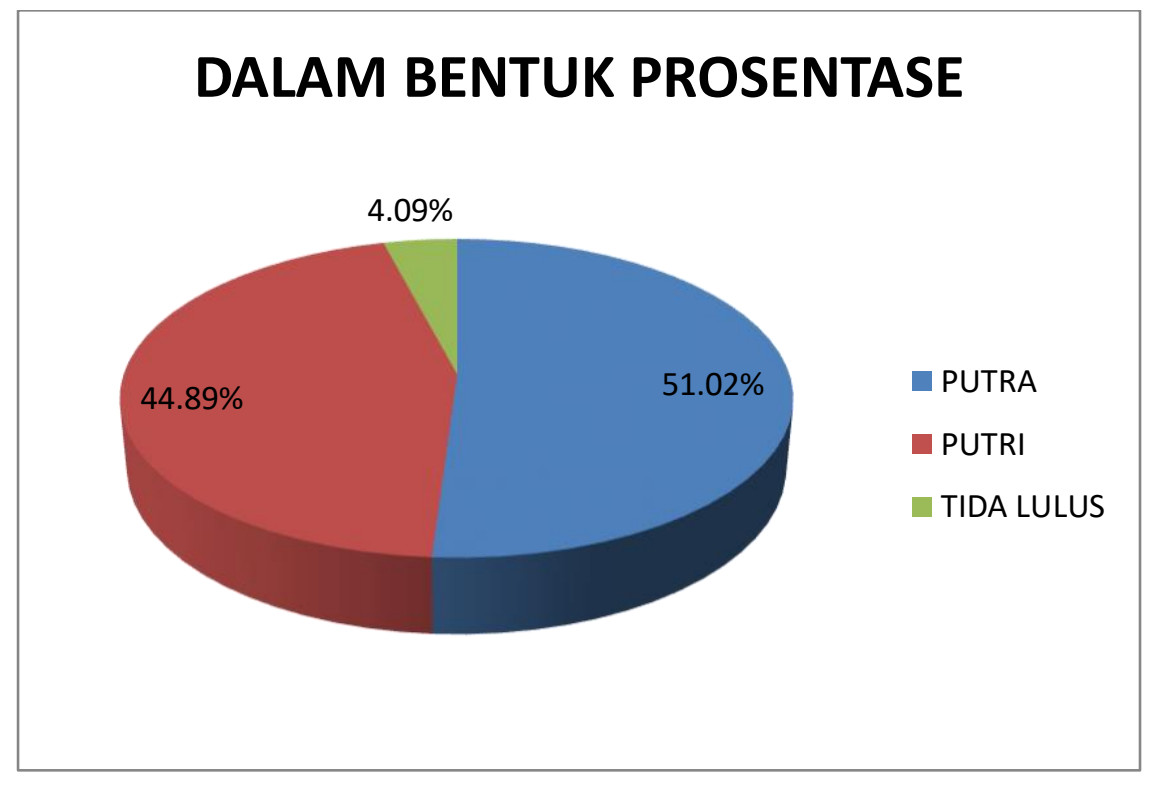

Gambar 6. Kelulusan Dalam Prosentase 


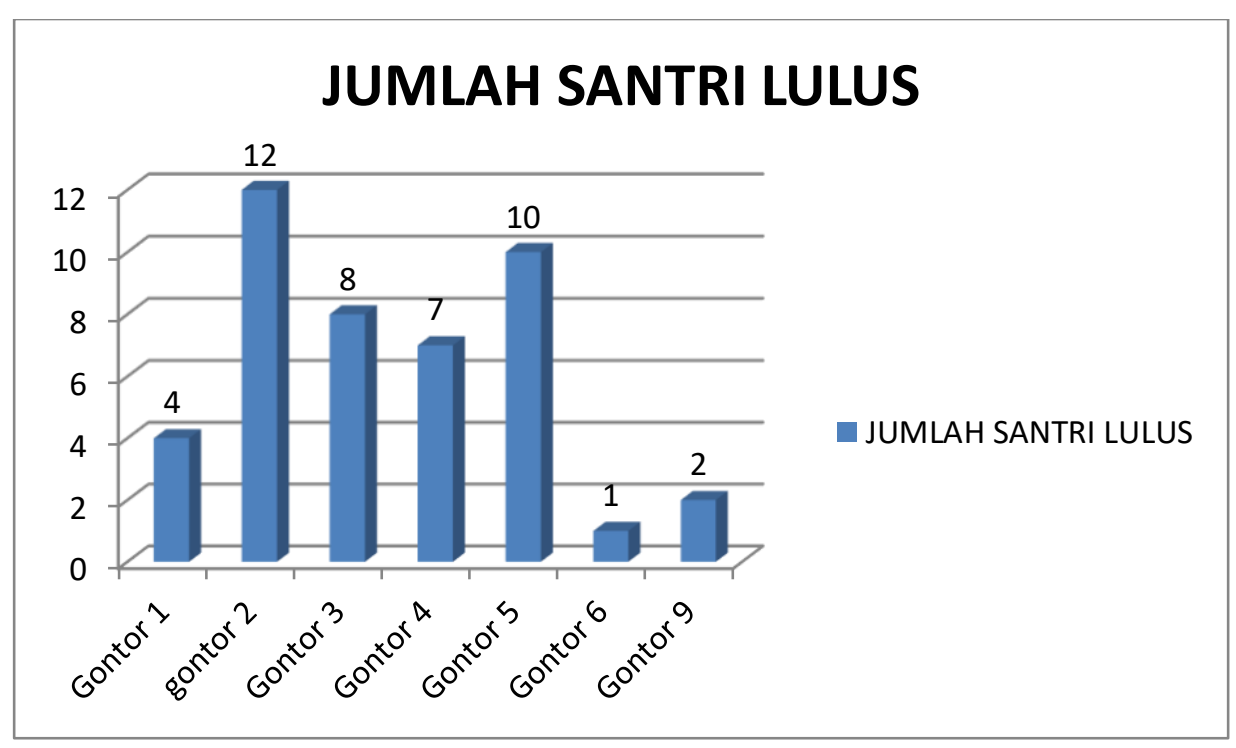

Gambar 7. Kelulusan Calon Santri Putra Berdasarkan Lokasi Pondok

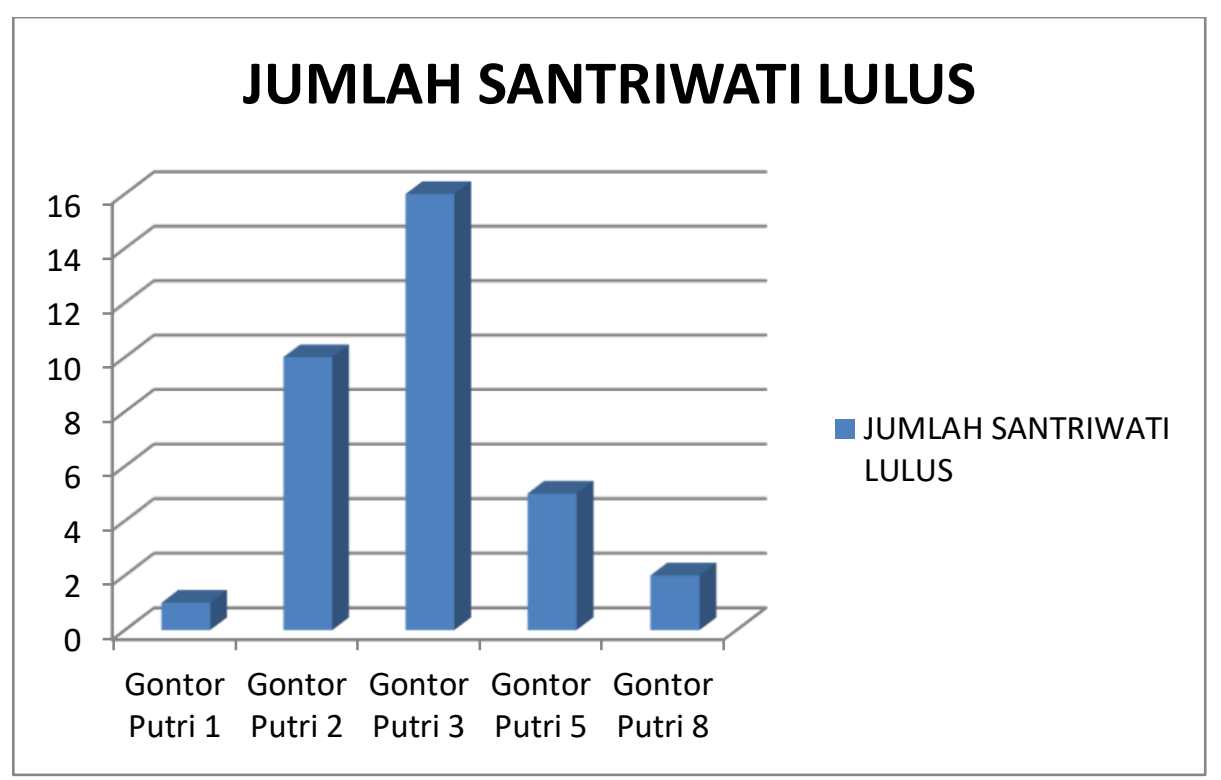

Gambar 8. Kelulusan Calon Santri Putri Berdasarkan Lokasi Pondok

\section{Pendampingan Calon Santri Pondok Gontor}

Sesuai dengan instruksi Pimpinan Pondok Gontor, semua peserta ujian masuk Pondok Gontor atau calon santri diharuskan berangkat tanpa mengikutsertakan wali. Sebagai pendamping, dipilihlah IKPM cabang di setiap kota/kabupaten di seluruh Indonesia yang merupakan jaringan alumni. Kebijakan ini diambil mengingat pandemi covid-19.

Sebagai bentuk pertanggungjawaban, pengabdian dilanjutkan dengan pendampingan peserta pelatihan. Dalam hal ini bekerjasama dengan IKPM Yogyakarta. Keberangkatan dikoordinir IKPM Yogyakarta dengan melibatkan para pengabdi. Keberangkatan dilaksanakan pada tanggal 17 Juni 2020 bertempat di Jogja Expo Center (JEC). Pendampingan dilaksanakan selama pendaftaran sampai dengan pengumuman kelulusan calon santri. Santri yang lulus akan diserahkan kepada Pondok Gontor dan yang belum lulus akan kembali ke Yogyakarta bersama dengan pendamping (Gambar 9). 

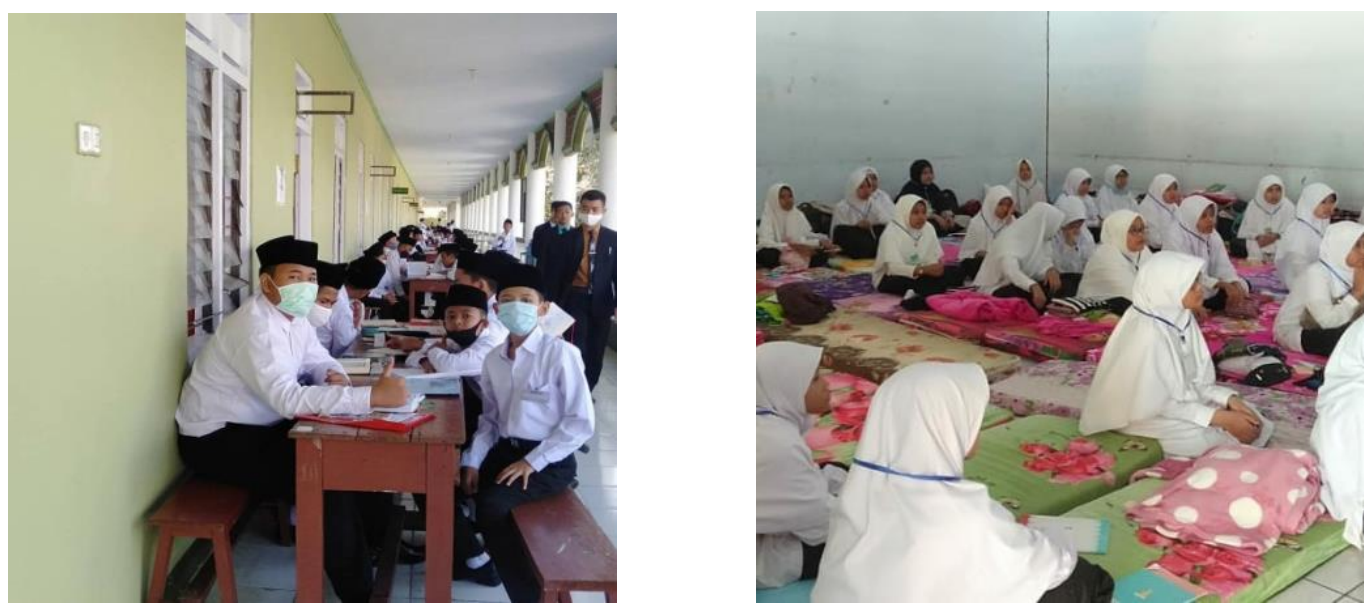

Gambar 9. Pendampingan Peserta Pelatihan Dalam Ujian Seleksi Masuk Pondok Gontor

\section{SIMPULAN}

Pelaksanaan Pelatihan Baca Al-Qur'an dan Pendampingan Calon Santri Gontor berjalan dengan baik. Hal ini merupakan tujuan utama dari persiapan masuk Pondok Gontor. Program pelatihan dan pendampingan merupakan bentuk nyata dari pengabdian. Hasilnya banyak dari peserta pelatihan yang lolos. Hal ini dbuktikan dengan tingginya prosentase kelulusan sebesar 95,91\%.

\section{UCAPAN TERIMAKASIH}

Pelaksana pengabdian kepada masyarakat ini mengucapkan terima kasih diucapkan kepada segenap IKPM Yogyakarta, Forum Mahasiswa Gontor Yogyakarta, dan Wali Calon Santri Pondok Gontor. Selain itu, ucapan yang tulus juga disampaikan atas dedikasi dan kontribusinya dalam pengabdian sekaligus mempersiapkan santri Pondok Gontor sebagai penerus estafet perjuangan bangsa dan negara.

\section{DAFTAR PUSTAKA}

Effendy, Ilham. 2016. "Pengaruh Pemberian Pre-Test Dan Post-Test Terhadap Hasil Belajar Mata Diklat HDW.DEV.100.2.a Pada Siswa SMK Negeri 2 Lubuk Basung." Jurnal Ilmiah Pendidikan 1(2):81-88.

Handayani, Iys Nur, and Suismanto. 2018. "Metode Sorogan Dalam Meningkatkan Kemampuan Membaca Alquran Pada Anak." GOLDEN AGE Jurnal Ilmiah Tumbuh Kembang Anak Usia Dini Vol. 3(2):105.

Hardoyo, Hafid. 2008. "Kurikulum Tersembunyi Pondok Modern Darussalam Gontor." AtTa'dib 4(2):191-208.

Ismail, Muhammad. 2011. "Sistem Pendidikan Pesantren Modern: Studi Kasus Pendidikan Pesantren Modern Darussalam Gontor Ponorogo.” Jurnal At-Ta'dib 6(1):147-66.

Nurhakim, Moh. 2018. "Imam Zarkasyi Dan Pembaharuan Pesantren : Rekonstruksi Aspek Kurikulum, Menejemen Dan Etika Pendidikan." Progresiva: Jurnal Pemikiran Dan Pendidikan Islam 7(1):1.

Sanusi, Muhammad Husein. 2016. Trimurti: Menelusuri Jejak, Sintesa Dan Genealogi Berdirinya Pondok Modern Darussalam Gontor. 1st ed. Bantul: Etifaq Production.

Syafe'i, Imam. 2017. "PONDOK PESANTREN: Lembaga Pendidikan Pembentukan Karakter." Al-Tadzkiyyah: Jurnal Pendidikan Islam 8:85-103.

Syamsuri, Joni,. 2016. "Eksistensi Dan Kontribusi Pondok Modern Darussalam Gontor Dalam Pembangunan Sumber Daya Manusia." At Ta'Dib 11(2).

Zarkasyi, Muhammad Ridlo. 2016. Ajaran Kiai Gontor: 72 Prinsip Hidup KH. Imam Zarkasyi. 1st ed. Jakarta: renebook. 